\title{
PENGARUH GOOD CORPORATE GOVERNANCE TERHADAP NILAI PERUSAHAAN
}

\author{
(Studi Empiris Pada Perusahaan Manufaktur yang Terdaftar
} di Bursa Efek Indonesia)

\author{
Yushita Marini $^{1)}$ dan Nisha Marina ${ }^{2)}$ \\ ${ }^{1)}$ Program Studi Akuntansi, Fakultas Ekonomi, Universitas Terbuka \\ UPBJJ-UT Banda Aceh Jl. Pendidikan, Banda Aceh, email : yushita@ecampus.ut.ac.id \\ ${ }^{2)}$ Program Studi Akuntansi, Fakultas Ekonomi, Universitas Terbuka \\ UPBJJ-UT Medan Jl. Bromo No. 29 Medan, email : nisha@ecampus.ut.ac.id
}

\begin{abstract}
This study aimed to get empirical evidence regarding the corporate governance mechanism proxied by the size of the board of commisioners, independent directors, the size of the board of directors and audit committees that affect the value of the company. This study using purposive sampling method for collecting samples of the companies listed in Indonesia Stock Exchange that publish the complete annual financial statements for 2010-2014, have the data necessary corporate governance in research, the company has never delisted and present its financial statements in Indonesian Rupiah, From the analysis of the study showed that the size of the board of commisioners, independent directors, and the size of the board of directors affect the value of the company, while the audit committee does not affect the value of the company.
\end{abstract}

Keywords : The Corporate Governance, The Board of commisioners, The Independent Directors, The Board of Directors, The Audit committee, The Value of The Company

\begin{abstract}
Abstrak: Penelitian ini bertujuan untuk mendapatkan bukti empiris mengenai mekanisme corporate governance yang diproksikan oleh ukuran dewan komisaris, komisaris independen, ukuran dewan direksi dan komite audit yang mempengaruhi nilai perusahaan. Penelitian ini menggunakan metode purposive sampling untuk pengumpulan sampel pada perusahaan yang terdaftar di Bursa Efek Indonesia yang mempublikasikan laporan keuangan tahunan lengkap periode 2010-2014, memiliki data corporate governance yang dibutuhkan dalam penelitian, perusahaan tersebut tidak pernah delisted dan menyajikan laporan keuangannya dalam mata uang Rupiah. Dari hasil analisis penelitian, menunjukkan bahwa ukuran dewan komisaris, komisaris independen, dan ukuran dewan direksi berpengaruh terhadap nilai perusahaan, sedangkan komite audit tidak berpengaruh terhadap nilai perusahaan.
\end{abstract}

\section{Kata kunci : Corporate Govermance, Dewan Komisaris, Komisaris Independen, Dewan} Direksi, Komite Audit, Nilai Perusahaan.

The Wall Street Crash pada tahun 1929 yang mengawali berlangsungnya era great depression $\mathrm{di}$ Amerika diyakini sebagai awal mula dilakukannya studi mendalam mengenai corporate governance. Adolf Berle dan Gardiner Means, dalam Berle and Means (1932) menyatakan bahwasanya terpisahnya pemilik dan pengontrol perusahaan disebabkan oleh pemilikan perusahaan yang menyebar (Talbot, 2008). Pemegang saham (principals) yang menyebar itu tidak memiliki pilihan selain menyewa orang lain atau manajer (agents) untuk mengelola perusahaan, yang kemudian melahirkan apa yang disebut dengan hubungan principals-agents. Hubungan principalagent memunculkan agency problem (Cheffin, 2003) dimana para manajer yang menjalankan perusahaan cenderung menyelewengkan uang pemilik perusahaan. Thomsen (2006) menyatakan bahwasanya mekanisme (kode) corporate governance di dunia secara khusus telah didesain untuk mengisi jurang ketidakseimbangan informasi antara investor dan perusahaan agar 
pengelola perusahaan (insiders) tidak berlaku semena-mena mengalihkan modal pemilik perusahaan (outsiders) untuk kepentingan pribadi mereka.

Ambruknya perusahaan-perusahaan publik di dunia pada awal dekade 2000-an, seperti Enron, World Com dan Tyco di Amerika Serikat, HIH Insurance dan One-Tel di Australia, London \& Commonwealth di Inggris dan lainnya telah memicu polemik dan pembahasan mengenai penerapan Corporate Governance perusahaan di seluruh dunia. Karena meskipun para perusahaan tersebut telah menerapkan corporate governance, namun praktik kecurangan masih tetap terjadi dan berakibat pada kehancuran perusahaan-perusahaan tersebut. Good Corporate Governance (GCG) dianggap mampu dijadikan salah satu solusi untuk diterapkan pada perusahaan agar terhindar dari kehancuran perusahaan yang disebabkan oleh mismanagement perusahaan maupun fraud yang dilakukan oleh manajemen puncak yang berlangsung dalam waktu lama dan tidak terdeteksi. Pada tahun 2002, Kongres Amerika mengesahkan undang-undang The Sarbanes-Oxley Act (SOX) yang mengatur penerapan corporate governance perusahaan di Amerika, dimana seluruh perusahaan yang terdaftar di Bursa Efek harus mematuhi peraturan didalamnya, jika tidak maka perusahaan tersebut akan terkena sanksi hukum sesuai ketentuan yang berlaku.

Di Indonesia, penerapan GCG dipicu oleh terjadinya krisis ekonomi asia pada tahun 1997. Salah satu penyebab krisis yang terjadi pada saat itu diantaranya dikarenakan oleh lemahnya pengawasan terhadap dewan direksi perusahaan yang seharusnya menjadi tanggung jawab dewan komisaris. (Herwidayatmo, 2000). Kolapsnya perusahaan-perusahaan besar, termasuk perusahaan perbankan, yang mengikuti terjun bebasnya nilai mata uang Rupiah, menyebabkan Indonesia membutuhkan dana bantuan dari pihak asing. The International Monetary Funds (IMF) bersedia memberikan dana kepada pemerintah, dengan salah satu syarat agar pemerintah berkomitmen memperbaiki sistem corporate governance perusahaan di Indonesia (Kurniawan dan Indriantoro, 2000).

Tujuan utama sebuah perusahaan adalah meningkatkan nilai perusahaan. Konflik keagenan yang berakibat pada timbulnya sifat opportunistic manajemen akan menyebabkan rendahnya kualitas laba. Rendahnya kualitas laba akan dapat membuat kesalahan pembuatan keputusan para pemakainya seperti investor dan kreditor, sehingga nilai perusahaan akan berkurang (Siallagan dan Machfoedz, 2006). Laba yang tidak menunjukkan informasi sebenarnya tentang kinerja manajemen dapat menyesatkan pihak pengguna laporan. Jika laba seperti ini digunakan oleh investor untuk membentuk nilai pasar perusahaan, maka laba tidak dapat menjelaskan nilai pasar yang sebenarnya (Budiono, 2005). Dalam hal ini, maka $G C G$ harus dapat memberikan insentif yang tepat untuk dewan direksi dan manajemen dalam rangka mencapai sasaran-sasaran yang ditentukan dari sisi kepentingan perusahaan dan para pemegang saham dan juga harus dapat memfasilitasi monitoring yang efektif, sehingga mendorong perusahaan untuk menggunakan sumber daya secara efisien (OECD, 1999). Terdapat empat mekanisme GCG yang bertujuan untuk mengurangi konflik keagenan yang sering digunakan 
dalam berbagai penelitian, yaitu komite audit, komisaris independen, kepemilikan institusional, dan kepemilikan manajerial (Rachmawati, 2007).

Dengan adanya mekanisme GCG ini dalam perusahaan, diharapkan pengawasan terhadap manajer perusahaan dapat lebih efektif sehingga dapat meningkatkan kinerja perusahaan dan nilai perusahaan. Jadi jika perusahaan menerapkan sistem GCG, maka diharapkan kinerja tersebut akan meningkat menjadi lebih baik, dengan meningkatnya kinerja perusahaan diharapkan juga dapat meningkatkan harga saham perusahaan sebagai indikator dari nilai perusahaan sehingga nilai perusahaan akan tercapai (Carningsih, 2009).

Penelitian ini bertujuan untuk memperoleh bukti empiris mengenai pengaruh mekanisme GCG yang diproksikan oleh oleh ukuran dewan komisaris, komisaris independen, ukuran dewan direksi, dan komite audit berpengaruh terhadap nilai perusahaan.

Hasil penelitian ini diharapkan dapat memberikan manfaat kepada para pihak, diantaranya:

a. Bagi peneliti dan pelaku akademis, untuk menambah pengetahuan mengenai pengaruh mekanisme GCG terhadap nilai perusahaan.

b. Bagi perusahaan, untuk dijadikan sumber acuan dalam penerapan mekanisme GCG di perusahaan.

Berdasarkan uraian pada latar belakang penelitian tersebut di atas, maka rumusan masalah pada penelitian ini adalah sebagai berikut: "Apakah mekanisme GCG yang diproksikan oleh ukuran dewan komisaris, komisaris independen, ukuran dewan direksi, dan komite audit berpengaruh terhadap nilai perusahaan?".

\section{KAJIAN PUSTAKA}

\section{Teori Keagenan}

Jensen dan Meckling (1976) menyatakan bahwa hubungan keagenan adalah sebuah kontrak antara manajer (agent) dengan pemegang saham (principal). Hubungan keagenan tersebut terkadang menimbulkan masalah antara manajer dan pemegang saham. Konflik yang terjadi karena manusia adalah makhluk ekonomi yang mempunyai sifat dasar mementingkan kepentingan diri sendiri. Pemegang saham dan manajer memiliki tujuan yang berbeda dan masing-masing menginginkan tujuan mereka terpenuhi. Akibat yang terjadi adalah munculnya konflik kepentingan. Pemegang saham menginginkan pengembalian yang lebih besar dan secepatcepatnya atas investasi yang mereka tanamkan sedangkan manajer menginginkan kepentingannya diakomodasi dengan pemberian kompensasi atau insentif yang sebesar-besarnya atas kinerjanya dalam menjalankan perusahaan.

\section{Mekanisme Corporate Governance dan Nilai Perusahaan}

Corporate governance merupakan suatu sistem yang mengatur dan mengendalikan perusahaan yang diharapkan dapat memberikan dan meningkatkan nilai perusahaan kepada para pemegang saham. Cadbury Committee (dalam Isgiyarta, 2005) mendefinisikan GCG sebagai seperangkat peraturan yang mengatur hubungan antara pemegang saham, pengelola perusahaan, pihak kreditor, pemerintah, karyawan serta pemegang kepentingan intern dan ekstern lainnya yang berkaitan dengan hak-hak dan kewajiban mereka, atau dengan kata lain suatu sistem yang 
mengatur dan mengendalikan perusahaan. Dengan demikian, penerapan GCG dipercaya dapat meningkatkan nilai perusahaan. Dey Report (1994) mengemukakan bahwa corporate governance yang efektif dalam jangka panjang dapat meningkatkan kinerja perusahaan dan menguntungkan para pemegang saham.

Menurut Linan (2000) terdapat empat prinsip dasar pengelolaan perusahaan yang baik. Keempat prinsip tersebut adalah :

1. Keadilan (fairness) yang meliputi, Perlindungan bagi seluruh hak pemegang saham, Perlakuan yang sama bagi para pemegang saham.

2. Transparansi (transparency) yang meliputi : Pengungkapan informasi yang bersifat penting, Informasi harus disiapkan, diaudit dan diungkapkan sejalan dengan pembukuan yang berkualitas, Penyebaran informasi harus bersifat adil, tepat waktu dan efisien.

3. Dapat dipertanggung jawabkan (accountability) yang meliputi pengertian bahwa : Anggota dewan direksi harus bertindak mewakili kepentingan perusahaan dan para pemegang saham, Penilaian yang bersifat independen terlepas dari manajemen, adanya akses informasi yang akurat, relevan dan tepat waktu.

4. Pertanggungjawaban (responsibility) meliputi : Menjamin dihormatinya segala hak pihakpihak yang berkepentingan, Para pihak yang berkepentingan harus mempunyai kesempatan untuk mendapatkan ganti rugi yang efektif atas pelanggaran hak-hak mereka. Dibukanya mekanisme pengembangan prestasi bagi keikutsertaan pihak yang berkepentingan, jika diperlukan maka para pihak yang berkepentingan harus mempunyai akses terhadap informasi yang relevan.

Tujuan utama perusahaan menurut theory of the firm adalah untuk memaksimumkan kekayaan atau nilai perusahaan (Salvatore, 2005). Memaksimalkan nilai perusahaan sangat penting artinya bagi suatu perusahaan, karena dengan memaksimalkan nilai perusahaan berarti juga memaksimalkan kesejahteraan pemegang saham yang merupakan tujuan utama perusahaan (Euis dan Taswan, 2002). Menurut Husnan (2000), nilai perusahaan merupakan harga yang bersedia dibayar oleh calon pembeli apabila perusahaan tersebut dijual. Sedangkan menurut Keown (2004) nilai perusahaan merupakan nilai pasar atas surat berharga hutang dan ekuitas perusahaan yang beredar. Semakin tinggi harga saham maka semakin tinggi pula nilai perusahaan. Nilai perusahaan yang tinggi menjadi keinginan para pemilik perusahaan, sebab dengan nilai yang tinggi menunjukan kemakmuran stakeholder yang juga tinggi.

\section{Ukuran Dewan Komisaris}

Ukuran dan komposisi dewan komisaris dapat membantu meningkatkan keefektifan kinerja dewan komisaris. Ukuran yang tidak seimbang dengan jumlah dewan direksi yang lebih banyak akan menyebabkan komisaris kesulitan ketika bernegosiasi dengan dewan direksi. Ukuran dewan komisaris yang pas dipengaruhi oleh berbagai hal, diantaranya adalah ukuran dewan direksi, karena jika jumlah anggota dewan komisaris lebih sedikit dari jumlah dewan direksi, maka ada kemungkina dewan komisaris akan mengalami tekanan psikologis pada saat mengadakan rapat yang 
membahas masalah strategis dengan dewan direksi. Untuk memperkecil kemungkinan tersebut, maka sebaiknya jumlah anggota dewan komisaris setidaknya sama dengan jumlah dewan direksi (Muntoro, 2007).

Penelitian yang dilakukan Yermack (1996), Beaslley (1996) dan Jensen (1993) juga menyimpulkan bahwa dewan komisaris yang berukuran kecil akan lebih efektif dalam melakukan tindakan pengawasan dibandingkan dewan komisaris berukuran besar. Ukuran dewan komisaris yang besar dianggap kurang efektif dalam menjalankan fungsinya karena sulit dalam komunikasi, koordinasi serta pembuatan keputusan.

\section{Komisaris Independen}

\section{Berdasarkan Keputusan BAPEPAM}

Nomor: KEP-643 /BL/2012 yang dimaksud dengan Komisaris Independen adalah anggota Komisaris yang memenuhi persyaratan : a) berasal dari luar Emiten atau Perusahaan Publik; b) Bukan merupakan orang yang bekerja pada Emiten dan Perusahaan Publik dan mempunyai wewenang dan tanggung jawab untuk merencanakan, memimpin, atau mengendalikan serta mengawasi kegiatan Emiten atau Perusahaan Publik dalam waktu 6 (enam) bulan terakhir; c) tidak mempunyai saham baik langsung maupun tidak langsung pada Emiten atau Perusahaan Publik; d) tidak mempunyai hubungan Afiliasi dengan Emiten atau Perusahaan Publik, Komisaris, Direksi, atau Pemegang Saham Utama Emiten atau Perusahaan Publik; e) tidak memiliki hubungan usaha baik langsung maupun tidak langsung yang berkaitan dengan kegiatan usaha Emiten atau Perusahaan Publik; dan f) tidak mempunyai hubungan yang dapat mempengaruhi kemampuannya untuk bertindak independen.

Komisaris independen diperlukan untuk meningkatkan independensi dewan komisaris terhadap kepentingan pemegang saham mayoritas dan benar-benar menempatkan kepentingan perusahaan diatas kepentingan lainnya. Jumlah komisaris independen harus sama banyak dengan anggota komisaris "non independen" agar memiliki kekuatan yang setara dalam perdebatan, terutama dalam pengambilan keputusan pemungutan suara/voting (Muntoro, 2007).

\section{Ukuran Dewan Direksi}

Ukuran dewan direksi adalah jumlah personel dewan direksi dalam suatu perusahaan. Jumlah personel dewan akan meningkatkan kinerja perusahaan yang semakin baik (Susanti, 2010). Lipton dan Lorch (1992) dalam Shakir (2010) menyatakan bahwa terdapat beberapa kekurangan dalam besarnya ukuran dewan direksi. Ukuran dewan direksi yang besar akan berakibat pada kurangnya diskusi yang berarti, sebab mengekspresikan pendapat dalam kelompok besar umumnya memakan waktu, sulit dan mengakibatkan kurangnya kekompakan pada dewan direksi.

\section{Komite Audit}

Komite Audit adalah komite yang dibentuk oleh dan bertanggung jawab kepada Dewan Komisaris dalam rangka membantu melaksanakan tugas dan fungsi Dewan Komisaris. Berdasarkan Kep. BAPEPAM Nomor: KEP-643 /BL/2012, tugas dan tanggung jawab komite audit diantaranya adalah: a) Melakukan penelaahan atas 
informasi keuangan yang akan dikeluarkan perusahaan seperti laporan keuangan, proyeksi, dan laporan lainnya terkait dengan informasi keuangan perusahaan; b) Melakukan penelaahan atas ketaatan perusahaan terhadap peraturan perundangundangan lainnya yang berhubungan dengan kegiatan perusahaan; c) Memberikan rekomendasi kepada Dewan Komisaris mengenai penunjukan Akuntan yang didasarkan pada independensi, ruang lingkup penugasan dan fee untuk disampaikan kepada Rapat Umum Pemegang Saham; d) Melakukan penelaahan atas pelaksanaan pemeriksaan oleh auditor internal dan pelaksanaan tindak lanjut oleh Direksi atas temuan auditor internal; e) Melakukan penelaahan terhadap aktivitas pelaksanaan manajemen risiko yang dilakukan oleh direksi; f) Menelaah pengaduan yang berkaitan dengan proses akuntansi dan pelaporan keuangan, dan manajemen risiko Emiten dan Perusahaan Publik; g) Menelaah dan memberikan saran kepada Dewan Komisaris terkait dengan potensi adanya benturan kepentingan; dan h) Menjaga kerahasiaan dokumen, data dan informasi perusahaan.

\section{Review Penelitian Terdahulu}

Dalam penelitian berjudul "Pengaruh Corporate Governance Terhadap Nilai Perusahaan di Bursa Efek Indonesia", Jakarta yang dilakukan oleh Saputra (2010) dengan sampel sejumlah 150 perusahaan manufaktur yang terdaftar di BEI periode 2002-2005 dengan hasil bahwasanya mekanisme corporate governance yang diwakilkan oleh kepemilikan keluarga, kepemilikan institusi, dan kepemilikan asing tidak berdampak signifikan terhadap nilai perusahaan, hanya kepemilikan manajemen yang berdampak signifikan dan positif terhadap nilai perusahaan.

Penelitian berjudul "Pengaruh Good Coporate Governance dan Pengungkapan Corporate Social Responsibility Terhadap Nilai Perusahaan (Studi Empiris pada Perusahaan Yang Terdaftar di Bursa Efek Indonesia Periode 20072010)" yang dilakukan oleh Reny dan Denies (2012), dengan sampel sebanyak perusahaan yang listed di BEI pada 2007-2010. Hasil penelitian ini menunjukkan: a) $G C G$ berpengaruh positif terhadap Nilai Perusahaan b) Pengungkapan CSR berpengaruh positif dan tidak signifikan terhadap Nilai Perusahaan c) $G C G$ dan Pengungkapan CSR berpengaruh positif terhadap Nilai Perusahaan pada perusahaan yang terdaftar di BEI periode 2007-2010.

Penelitian yang dilakukan oleh Mukhtaruddin, Relasari dan Felmania (2014) bertema "Good Corporate Governance Mechanism, Corporate Responsibility Disclosure on Firm Value: Empirical Study on Listed Company in Indonesia Stock Exchange", dengan sampel berjumlah 33 perusahaan yang terdaftar di BEI selama periode 2010-2011 yang menunjukkan hasil dimana variabel dewan komisaris, kepemilikan institusi, komisaris independen, komite audit, dan pengungkapan CSR tidak memiliki pengaruh signifikan terhadap nilai perusahaan, sedangkan kepemilikan manajerial memiliki pengaruh signifikan terhadap nilai perusahaan.

Penelitian ini mengambil ide dari penelitianpenelitian sebelumnya tersebut di atas, namun penulis memilih berkonsentrasi pada pengaruh mekanisme GCG terhadap nilai perusahaan dan 
rentang waktu periode sampel yang digunakan adalah perusahaan manufaktur yang terdaftar di BEI pada 2010-2014.

\section{Kerangka Konsep}

Kerangka konsep merupakan model yang menerangkan bagaimana hubungan suatu teori dengan faktor-faktor yang penting yang telah diketahui dalam suatu masalah tertentu. Kerangka konseptual akan menghubungkan secara teoretis antara variabel-variabel penelitian, yaitu antara variabel bebas dengan variabel terikat (Erlina, 2011). Berdasarkan latar belakang dan tinjauan pustaka yang telah diuraikan di atas, maka kerangka konseptual dari penelitian ini dan penjelasannya adalah sebagai berikut:

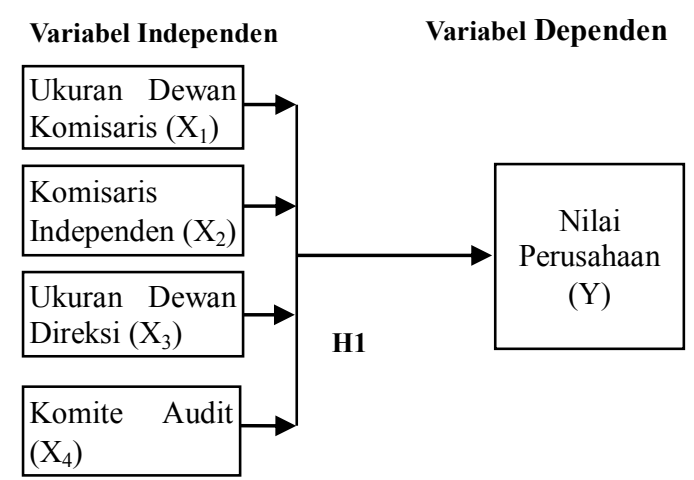

Gambar 1. Kerangka Konsep

Penelitian ini dilakukan dengan tujuan untuk mengetahui dan menganalisa pengaruh variabel GCG (jumlah dewan komisaris, independensi dewan komisaris, ukuran dewan direksi, dan jumlah anggota komite audit), baik secara parsial (masing-masing) maupun secara simultan (bersama-sama) terhadap nilai perusahaan perbankan yang go public.

\section{Hipotesis Penelitian}

Berdasarkan landasan teori dan temuan penelitian sebelumnya yang telah dijelaskan di atas, maka dapat dirumuskan hipotesis penelitian ini adalah sebagai berikut :

H1 : Ukuran dewan komisaris berpengaruh terhadap nilai perusahaan.

H2 : Independensi dewan komisaris berpengaruh terhadap nilai perusahaan.

H3 : Ukuran dewan direksi berpengaruh terhadap nilai perusahaan.

H4 : Jumlah komite audit berpengaruh terhadap nilai perusahaan.

\section{METODE PENELITIAN}

\section{Populasi dan Sampel Penelitian}

Perbedaan jenis industri emiten yang terdaftar di BEI kemungkinan dapat mempengaruhi daya klasifikasi model. Oleh karena itu populasi pada penelitian ini hanya difokuskan pada kelompok industri yang sejenis, yaitu perusahaan manufaktur yang terdaftar di Bursa Efek Indonesia pada periode 2010-2014. Data populasi dan sampel pada penelitian ini diunduh dari www.idx.co.id.

\section{Metode Pengumpulan Sampel}

Metode pengambilan sampel yang digunakan adalah metode purposive sampling, yaitu metode pengambilan sampel dengan menggunakan kriteria tertentu. Kriteria sampel yang digunakan dalam penelitian ini adalah:

a. perusahaan manufaktur yang terdaftar pada Bursa Efek Indonesia dan mempublikasikan laporan keuangan tahunan yang lengkap 
dalam periode 2010-2014 dan memiliki data corporate governance yang dibutuhkan

b. perusahaan tidak pernah delisted dalam periode penelitian 2010-2014;

c. perusahaan menyajikan laporan keuangannya dalam mata uang Rupiah.

\section{Definisi Operasional dan Pengukuran} Variabel Dependen

Variabel dependen (variabel output/ kriteria / konsekuen / endogen / terikat) adalah variabel yang dipengaruhi atau yang menjadi akibat karena adanya variabel bebas. Adapun variabel dependen pada penelitian ini adalah Nilai Perusahaan. Pada penelitian ini Nilai Perusahaan diukur dengan rasio Tobin's Q. Rasio Tobin's Q didefinisikan sebagai nilai pasar dari ekuitas ditambah dengan total kewajiban dan kemudian dibagi dengan total aktivanya (Chong dan López-de-Silanes 2006), dengan rumus sebagai berikut:

$$
\text { Tobin's } \mathrm{Q}=(\mathrm{MVE}+\mathrm{DEBT}) / \mathrm{TA}
$$

Keterangan:

MVE : harga penutupan saham di akhir tahun buku x jumlah saham biasa yang beredar

DEBT : (utang lancar - aktiva lancar)+ nilai buku persediaan + utang jangka panjang

TA : nilai buku total aktiva

\section{Variabel Independen}

Variabel Independen (variabel stimulus/ prediktor / antecendent / eksogen /bebas) adalah variabel yang mempengaruhi atau yang menjadi sebab perubahan atau timbulnya variabel dependen (terikat). Adapun variabel independen pada penelitian ini adalah sebagai berikut :

1. Ukuran Dewan Komisaris : adalah jumlah anggota dewan komisaris dalam suatu perusahaan, yang ditetapkan dalam jumlah satuan (Siallagan \& Machfoedz, 2006). Semakin banyak jumlah anggota dewan komisaris maka mekanisme dalam memonitoring manajemen akan semakin baik, tentunya kepercayaan para pemegang saham juga akan semakin tinggi kepada perusahaan.

Ukuran Dewan Komisaris $=\Sigma$ Anggota Dewan Komisaris

2. Komisaris Independen : merupakan semua komisaris yang tidak memiliki kepentingan bisnis yang substansial dalam perusahaan. Independensi dewan komisaris diukur dari prosentase komisaris independen terhadap total dewan komisaris yang ada (Carningsih, 2009). Komisaris independen yang memiliki sekurang-kurangnya 30\%) dari jumlah seluruh anggota komisaris, berarti telah memenuhi pedoman GCG guna menjaga independensi, pengambilan keputusan yang efektif, tepat, cepat.

Independensi Dewan Komisaris =

$\underline{\Sigma \text { Komisaris Independen }}$

$\Sigma$ Anggota Dewan Komisaris

3. Ukuran Dewan Direksi : adalah jumlah anggota dewan direksi dalam suatu perusahaan, yang ditetapkan dalam jumlah satuan (Siallagan \& Machfoedz, 2006).

Ukuran Dewan Direksi $=\Sigma$ Anggota

Dewan Direksi

4. Komite Audit diukur dengan anggota komite audit yang dimiliki suatu perusahaan (Siallagan \& Machfoedz, 2006).

Jumlah Komite Audit $=\Sigma$ Anggota Komite Audit 


\section{Statistik Deskriptif dan Pengujian Hipotesis}

Analisis data dilakukan dengan menggunakan program Statistical Package for Social Science (SPSS). Statistik deskriptif penelitian menggunakan pengukuran mean, median, dan standar deviasi. Sedangkan untuk menguji pengaruh Ukuran dewan komisaris, Komisaris independen, Ukuran dewan direksi, dan Komite Audit terhadap nilai perusahaan diuji dengan menggunakan persamaan:

$$
\mathrm{y}=\mathrm{a}+\mathrm{b}_{1} \mathrm{x}_{1}+\mathrm{b}_{2} \mathrm{x}_{2}+\mathrm{b}_{3} \mathrm{x}_{3}+\mathrm{b}_{4} \mathrm{x}_{4}+e
$$

\section{Keterangan :}

y = nilai pasar perusahaan, diukur dengan rata-rata Tobin's Q

$\mathrm{a}=$ konstanta

$e=$ erorr term

$\mathrm{b}_{1}-\mathrm{b}_{4}=$ koefisien regresi dari tiap-tiap variabel independen

$\mathrm{x}_{1}=$ ukuran dewan komisaris

$\mathrm{x}_{2}=$ komisaris independen

$\mathrm{x}_{3}=$ ukuran dewan direksi

$\mathrm{x}_{4} \quad=$ komite audit

\section{HASIL DAN PEMBAHASAN}

\section{Hasil Pengumpulan Data}

Berdasarkan kriteria pengambilan sampel yang telah dijabarkan sebelumnya maka diperoleh sampel penelitian yang diperinci sebagai berikut :

Tabel 1. Sampel Penelitian

\begin{tabular}{lr}
\hline \multicolumn{1}{c}{ Kriteria Sampel } & Jumlah \\
\hline (A) Jumlah Populasi & 142 \\
(B) Jumlah perusahaan dengan data & 64 \\
& yang tidak lengkap dan/atau \\
& pernah delisted di BEI dalam \\
& rentang tahun 2010-2014 (tahun \\
& penelitian) \\
(C) Jumlah perusahaan dengan data & \\
& dalam mata uang asing (selain \\
& Rupiah) \\
\hline (D) Total sampel (A) - (B) - (C) & 46 \\
\hline
\end{tabular}

\section{Statistik Deskriptif}

Tabel 2. Descriptive Statistics

\begin{tabular}{|c|r|r|r|r|r|}
\hline & $\mathrm{N}$ & Min & Max & Mean & Std. Dev \\
\hline $\mathrm{X}_{1}$ & 160 & 2 & 11 & 4,23 & 2,035 \\
$\mathrm{X}_{2}$ & 160 & .20 & .80 & .3960 & .1183 \\
$\mathrm{X}_{3}$ & 160 & 1 & 10 & 4,52 & 0 \\
$\mathrm{X}_{4}$ & 160 & 2 & 5 & 3,11 &, 777 \\
$\mathrm{Y}$ & 160 & -.46 & 1,43 & 15.427 & 115.9 \\
Valid & & & 8.63 & 1 & 7159 \\
$\mathrm{~N}$ & & & & & \\
& & & & & \\
\hline
\end{tabular}

Variabel dewan komisaris memiliki nilai terendah sebesar 2 dan nilai tertinggi sebesar 11 , nilai rata-rata sebesar 4,23. Pada variabel komisaris independen nilai terendah 0,20 dan nilai tertinggi 0,80 dengan nilai rata-rata 0,3960 . Variabel dewan direksi nilai terendah sebesar 1 , nilai tertinggi 10 dengan nilai rata-rata sebesar 4,52. Variabel komite audit nilai terendah sebesar 2, nilai tertinggi 5 dengan nilai rata-rata 3,11. Pada variabel nilai perusahaan nilai terendah $-0,46$, nilai tertinggi $1,438.63$ dengan nilai rata-rata 15,4271 .

\section{Pengujian asumsi klasik}

\section{Uji Normalitas}

Hasil uji normalitas Kolmogrov-Smirnov menunjukkan bahwa nilai sig 0,000 lebih kecil dari nilai alpha 0,005 , hal ini menunjukkan bahwa hasil tidak berdistribusi dengan normal.

Tabel 3. One-Sample Kolmogorov-Smirnov Test sebelum transformasi

\begin{tabular}{|lr|r|}
\hline & & \multicolumn{1}{|c|}{$\begin{array}{c}\text { Standardize } \\
\text { d Residual }\end{array}$} \\
\hline $\mathrm{N}$ & & 160 \\
Normal & Mean &, 0000000 \\
Parameters & Std. Deviation &, 98734126 \\
Most Extreme & Absolute &, 360 \\
Differences $\quad$ Positive &, 360 \\
& Negative &,- 242 \\
\multicolumn{2}{|c|}{ Kolmogorov-Smirnov Z } & 4,560 \\
Asymp. Sig. (2-tailed) &, 000 \\
\hline
\end{tabular}

b. Calculated from data. 
Untuk mendapatkan hasil pengujian yang lebih baik dan valid, maka cara mengatasi pelanggaran ini dengan mentransformasi data mentah ke dalam bentuk logaritma natural dari masing-masing data yang akan di uji (Ghozali, 2005). Hasil pengujian normalitas setelah di transformasi menunjukkan nilai sig 0,146 dengan nilai alpha 0,05 maka data berdistribusi dengan normal.

Tabel 4. One-Sample Kolmogorov-Smirnov Test setelah transformasi

\begin{tabular}{|cc|r|}
\hline & & $\begin{array}{r}\text { Standardiz } \\
\text { ed Residual }\end{array}$ \\
\hline $\mathrm{N}$ & & 154 \\
Normal & Mean &, 0000000 \\
Parameters & a,b & Std. \\
& Deviation &, 98684153 \\
Most & Absolute &, 092 \\
Extreme & Positive &, 092 \\
Differences & Negative &,- 048 \\
Kolmogorov-Smirnov Z & 1,144 \\
Asymp. Sig. (2-tailed) &, 146 \\
\hline
\end{tabular}

a. Test distribution is Normal.

b. Calculated from data.

\section{Uji Multikolinearitas}

Tabel 5. Coefficients ${ }^{\mathrm{a}}$

\begin{tabular}{|c|c|c|c|c|c|c|c|}
\hline \multirow[b]{2}{*}{ Model } & \multicolumn{2}{|c|}{$\begin{array}{l}\text { Unstandard } \\
\text { Coeff. }\end{array}$} & \multirow{2}{*}{$\begin{array}{c}\begin{array}{c}\text { Std } \\
\text { Coeff. }\end{array} \\
\text { Beta }\end{array}$} & \multirow[b]{2}{*}{$\mathrm{t}$} & \multirow[b]{2}{*}{ Sig. } & \multicolumn{2}{|c|}{$\begin{array}{l}\text { Collinearity } \\
\text { Statistics }\end{array}$} \\
\hline & B & $\begin{array}{l}\text { Std. } \\
\text { Error }\end{array}$ & & & & $\begin{array}{l}\text { TO } \\
\mathrm{L}\end{array}$ & VIF \\
\hline $\begin{array}{l}\text { (Const } \\
\text {.) }\end{array}$ & $\begin{array}{r}- \\
5,456\end{array}$ & $\begin{array}{r}1,0 \\
78\end{array}$ & & 5,062 & 000 & & \\
\hline LN_X & 1 & ,34 & ,31 & 3,5 & & & 1, \\
\hline 1 & 231 & 3 & 4 & 90 & 000 & 576 & 736 \\
\hline LN_X & - & , 40 & - & - & & & 1, \\
\hline 2 & ,842 & 0 & , 150 & 2,107 & 037 & 873 & 146 \\
\hline LN_X & 1, & ,37 & 27, & 3,0 & & & 1, \\
\hline 3 & 142 & 4 & 7 & 51 & 003 & 535 & 870 \\
\hline LN_X & 1 & ,96 & , 10 & 1,4 & & & 1 \\
\hline $4^{-}$ & 356 & 6 & 2 & 04 & 163 & 836 & 196 \\
\hline
\end{tabular}

Berdasarkan tabel 5 di atas terlihat bahwa semua nilai VIF dari hasil regresi parsial di bawah 10. Hal ini menunjukkan bahwa tidak terjadi multikolinearitas pada keempat variabel penelitian tersebut.

\section{Uji Autokorelasi}

Tabel 6. Uji Autokolerasi

\begin{tabular}{|r|r|r|r|r|}
\hline Mod & R & R Square & $\begin{array}{r}\text { Adjusted } \\
\text { R Square }\end{array}$ & $\begin{array}{c}\text { Std. Error } \\
\text { of the Estimate }\end{array}$ \\
\hline 1 & $\begin{array}{r}, 6 \\
09^{\mathrm{a}}\end{array}$ &, 371 &, 349 & 1,28478 \\
\hline
\end{tabular}

LN_X1, LN_X3

Berdasarkan tabel 6. di atas terlihat bahwa nilai $\mathrm{R}^{2}$ sebesar 0,371 dan jumlah pengamatan sebanyak 160, maka X2 hitung sebesar (159 x $0,371)=58,989$. Sedangkan nilai X2 tabel dengan df: $(3 ; 0,05)$ sebesar 7,815. Karena nilai X2 hitung $(58,989)<\mathrm{X} 2$ tabel $(7,815)$. Maka persamaan regresi tidak mengandung masalah autokorelasi.

\section{Uji Heteroskedastisitas}

Tabel 7. Uji Heteroskedatisitas

\begin{tabular}{|r|r|r|r|c|}
\hline $\begin{array}{c}\text { M } \\
\text { od }\end{array}$ & $\mathrm{R}$ & $\begin{array}{r}\mathrm{R} \\
\text { Square }\end{array}$ & $\begin{array}{c}\text { Adjust } \\
\text { ed } \mathrm{R} \\
\text { Square }\end{array}$ & $\begin{array}{c}\text { Std. Error } \\
\text { of the } \\
\text { Estimate }\end{array}$ \\
\hline 1 &, $682^{\mathrm{a}}$ &, 465 &, 411 & 2,37006 \\
\hline
\end{tabular}

a. Predictors: (Constant), $\ln \times 3 \ln \times 4, \ln \times 2 \operatorname{In} \times 4$ LN_X1, LN_X4, sqr_Inx2, $\ln \times 2$ - Inx3, sqr_Inx3, sqr_Inx1, Inx1_Inx2, sqr_Inx4, Inx1_Inx3, Inx1_Inx4, LN_X2, LN_X3

Tabel 8. ANOVA

\begin{tabular}{|c|c|c|c|c|c|}
\hline Model & $\begin{array}{c}\text { Sum } \\
\text { of } \\
\text { Squares }\end{array}$ & $\begin{array}{c}\mathrm{d} \\
\mathrm{f}\end{array}$ & $\begin{array}{c}\text { Mea } \\
\mathrm{n} \\
\text { Square }\end{array}$ & $\mathrm{F}$ & $\begin{array}{c}\text { Si } \\
\mathrm{g} .\end{array}$ \\
\hline Regr. & 678,863 & 14 & 48,490 & 8,632 &, $000^{\mathrm{a}}$ \\
Resid & 780,787 & 139 & 5,617 & & \\
Total & 1459,650 & 153 & & & \\
a. Predictors: (Constant), Inx3_Inx4, Inx2_Inx4, LN_X1, \\
LN_X4, sqr_Inx2, Inx2_Inx3, sqr_Inx3, sqr_Inx1, Inx1_ \\
Inx2, sqr_Inx4, Inx1_Inx3, Inx1_Inx4, LN_X2, LN_X3 \\
b. Dependent Variable: u3
\end{tabular}

Berdasarkan output di atas dapat diketahui bahwa pada model regresi tidak terjadi gejala heteroskedastisitas. Hal ini berdasarkan nilai $\mathrm{X}$ hitung $(74,4)<X$ tabel $(23,685)$. 


\section{Uji Regresi Berganda}

Tabel 9. Uji Regresi Berganda

\begin{tabular}{|c|c|c|c|c|c|}
\hline \multicolumn{6}{|c|}{ Coefficients $^{\mathrm{a}}$} \\
\hline \multirow{2}{*}{ Model } & $\begin{array}{l}\text { Unst } \\
\text { zed Coe }\end{array}$ & $\begin{array}{l}\text { ndardi } \\
\text { cients }\end{array}$ & $\begin{array}{l}\text { Stan } \\
\text { dr } \\
\text { Coeff. }\end{array}$ & \multirow{2}{*}{$t$} & \multirow{2}{*}{$\begin{array}{l}\mathrm{Si} \\
\mathrm{g} .\end{array}$} \\
\hline & $B$ & $\begin{array}{l}\text { St } \\
\text { d. } \\
\text { Error }\end{array}$ & Beta & & \\
\hline $\begin{array}{l}\text { (Con } \\
\text { st) }\end{array}$ & $\begin{array}{c}- \\
5,456\end{array}$ & $\begin{array}{c}1 \\
078\end{array}$ & & $\begin{array}{c}- \\
5,062\end{array}$ & $0^{, 00}$ \\
\hline$\underset{\mathrm{X} 1}{\mathrm{LN}}$ & $\begin{array}{l}1,23 \\
1\end{array}$ & $43^{, 3}$ & ,314 & $\begin{array}{l}3,5 \\
90\end{array}$ & $0^{, 00}$ \\
\hline $\begin{array}{l}\mathrm{LN}_{\mathrm{X}} \\
\mathrm{X} 2\end{array}$ & , 842 & $00^{, 4}$ & $\begin{array}{r}- \\
, 150\end{array}$ & $\begin{array}{c}- \\
2,107\end{array}$ & $7^{, 03}$ \\
\hline $\begin{array}{l}\mathrm{LN}_{-} \\
\mathrm{X} 3\end{array}$ & $\begin{array}{l}1,14 \\
2\end{array}$ & $74^{, 3}$ & ,277 & $\begin{array}{c}3,0 \\
51\end{array}$ & $3^{, 00}$ \\
\hline $\mathrm{XN}_{-}^{\mathrm{LN}}$ & $\begin{array}{l}1,35 \\
6\end{array}$ & $66^{, 9}$ & , 102 & $\begin{array}{c}1,4 \\
04\end{array}$ & $3^{, 16}$ \\
\hline
\end{tabular}

Berdasarkan hasil perhitungan regresi secara keseluruhan, diperoleh hasil persamaan regresi sebagai berikut :

$$
\begin{aligned}
\mathrm{y}= & -5,456+1,231\left(\mathrm{x}_{1}\right)-0,842\left(\mathrm{x}_{2}\right)+ \\
& 1,142\left(\mathrm{x}_{3}\right)+1,356\left(\mathrm{x}_{4}\right)+e
\end{aligned}
$$

Konstanta sebesar $-5,456$ artinya jika ukuran dewan komisaris, komisaris independe, dewan direksi dan komite audit nilainya adalah 0 , maka maka nilai perusahaan adalah $-5,456$. Koefisien regresi variabel ukuran dewan komisaris $\left(\mathrm{x}_{1}\right)$ sebesar 1,231 artinya jika variabel independen lain nilainya tetap dan ukuran dewan komisaris mengalami kenaikan sebesar 1 orang, maka nilai perusahaan akan mengalami kenaikan sebesar 1,231. Koefisien regresi variabel komisaris independen $\left(\mathrm{x}_{2}\right)$ sebesar -0,842 artinya jika variabel independen lain nilainya tetap dan dan komisaris independen mengalami kenaikan sebesar 1, maka nilai perusahaan akan menurun sebesar $-0,842$. Koefisien regresi variabel dewan direksi sebesar 1,142 artinya jika variabel independen lain nilainya tetap dan dewan direksi mengalami kenaikan 1, maka nilai perusahaan akan mengalamai kenaikan sebesar 1,142. Koefisien variabel komite audit sebesar 1,356, artinya jika variabel independen lain nilainya tetap dan komite audit mengalami kenaikan 1 maka nilai perusahaan akan mengalami kenaikan sebesar 1,356.

\section{HASIL DAN PEMBAHASAN}

\section{Pengaruh Dewan Komisaris Terhadap Nilai Perusahaan}

Hasil pengujian pengaruh dewan komisaris terhadap nilai perusahaan menunjukkan nilai signifikan sebesar $0,000<$ alpha 0,05 , maka jumlah dewan komisaris berpengaruh terhadap nilai perusahaan. Dewan komisaris bertugas melakukan pengawasan atas kinerja perusahaan yaitu untuk memastikan bahwa manajemen telah benar-benar bekerja demi kepentingan perusahaan sesuai strategi yang ditetapkan serta menjaga kepentingan para pemegang saham. Dengan adanya tugas dewan komisaris tersebut maka akan semakin baik penerapan Good Corporate Governance pada perusahaan. Penerapan GCG yang baik maka akan memberikan pengaruh terhadap nilai perusahaan.

\section{Pengaruh Komisaris Independen Terhadap} Nilai Perusahaan

Hasil pengujian pengaruh komisaris independen terhadap nilai perusahaan menunjukkan nilai signifikan $0,037<$ alpha 0,05 , maka jumlah komisaris independen berpengaruh terhadap nilai perusahaan. Proporsi dewan komisaris yang berasal dari luar perusahaan atau komisaris independen juga dapat mempengaruhi 
kinerja perusahaan yang bertindak sebagai penengah dalam perselisihan yang terjadi di antara para manajer internal dan mengawasi kebijakan manajemen serta memberikan nasihat kepada manajemen. Komisaris independen dapat memberikan pengawasan terhadap perusahaan secara objektif, menjamin pengelolaan yang bersih dan sehatnya operasi perusahaan dalam mendukung kinerja perusahaan. Maka semakin tinggi independensi dan efektivitas corporate board dapat meningkatkan nilai perusahaan.

\section{Pengaruh Dewan Direksi Terhadap Nilai Perusahaan}

Hasil pengujian pengaruh dewan direksi terhadap nilai perusahaan menunjukkan nilai signifikan sebesar $0,003<$ alpha 0,05 , maka dewan direksi bepengaruh terhadap nilai perusahaan. Dewan direksi diberi tugas dan tanggung jawab melakukan pengawasan pengelolaan di dalam perusahaan dan melaporkan segala sesuatu yang terkait perusahaan kepada dewan komisaris. Agar pelaksanaan tugas direksi dapat berjalan secara efektif, salah satu prinsip yang perlu dipenuhi adalah komposisi direksi harus sedemikian rupa sehingga memungkinkan pengambilan keputusan secara efektif, tepat dan cepat, serta dapat bertindak independen (komite nasional kebijakan governance, 2006). Pelaksanaan tugas yang dilakukan oleh dewan direksi dengan hasil yang baik maka kinerja perusahaan akan meningkat dan pada akhirnya akan meningkatkan nilai perusahaan.

\section{Pengaruh Komite Audit terhadap Nilai Perusahaan}

Hasil pengujian pengaruh komite audit terhadap nilai perusahaan menunjukkan nilai signifikan sebesar $0,163>$ alpha 0,05 , maka komite audit tidak berpengaruh terhadap nilai perusahaan. Hal ini dapat dijelaskan bahwa ada kemungkinan disebabkan karena rendahnya pertemuan rutin komite audit sehingga masalahmasalah yang terkait dengan laporan keuangan perusahaan tidak dapat dibahas dengan eksternal auditor, intenal auditor, dewan direksi dan dewan komisaris. Menurut peraturan Bapepam No: KEP41/PM/ 2003 mengatakan bahwa komite audit mengadakan rapat sekurang-kurangnya sekali dalam 1 (satu) bulan (Khomsiyah, Jansin, dan Aditya, 2005). Kemungkinan juga bisa terjadi disebabkan keberadaan anggota komite audit bukan merupakan jaminan bahwa kinerja perusahaan akan semakin baik, sehingga pasar menganggap komite audit bukanlah faktor yang mereka pertimbangkan dalam mengapresiasi nilai perusahaan.

\section{KESIMPULAN DAN SARAN}

\section{Kesimpulan}

1. Dewan komisaris berpengaruh terhadap nilai perusahaan.

2. Komisaris independen berpengaruh terhadap nilai perusahaan.

3. Dewan direksi berpengaruh terhadap nilai perusahaan.

4. Komite audit tidak berpengaruh terhadap nilai perusahaan. 


\section{Saran}

1. Peneliti berikutnya agar mengambil sampel yang lebih luas rentang tahun penelitian yang lebih panjang;

2. Peneliti berikutnya dapat menggunakan perusahaan yang memiliki kurs mata uang asing (selain Rupiah) sebagai sampel, dengan mengkonversi nilai mata uang tersebut ke Rupiah sesuai nilai tukar pada masa penelitian.

\section{DAFTAR PUSTAKA}

Badan Pengawas Pasar Modal. (2012). Kep. BAPEPAM Nomor: KEP-643/BL/2012 Tentang Pembentukan dan Pedoman Pelaksanaan Kerja Komite Audit. www. bapepam.go.id.

Carningsih. (2009). Pengaruh Good Corporate Governance Terhadap Hubungan Antar Kinerja Keuangan Dengan Nilai Perusahaan. Fakultas Ekonomi Universitas Guna Dharma.

Erlina dan Mulyani, S. (2007). Metodologi Penelitian Bisnis Untuk Akuntansi \& Manajemen. Medan: USU Press.

Ghozali, Imam. (2006). Aplikasi Analisis Multivarite dengan SPSS. Cetakan Keempat. Semarang: Badan Penerbit Universitas Diponegoro.

Herwidayatmo. (2000). Implementasi GCG untuk Perusahaan Publik di Indonesia. Majalah Usahawan Th XXIX (10).

Kurniawan, M. Dudi, and Nur Indriantoro. (2000). Corporate Governance in Indonesia. Paper presented at the OECD Second Asian Roundtable on Corporate Governance and Accountability, 31 May-2
June, Hong Kong, China.

Linnan, David K. (2000). Keberadaan Good Corporate Governance dalam masyarakat Bisnis Sekarang dan Masa mendatang. Yogyakarta: Program Magister Hukum. UGM.

Meckling, William H. (1976). Theory of the Firm: Managerial Behavior, Agency Costs and Ownership Structure, Journal of Financial Economics, 3(4), pp. 305-360.

Mukhtaruddin, Relasari, dan Felmania, M. (2014). Good Corporate Governance Mechanism, Corporate Social Responsibility Disclosure on Firm Value: Empirical Study on Listed Company in Indonesia Stock Exchange. International Journal of Finance \& Accounting Studies.

Muntoro, Ronny Kusuma. (2007). Membangun Dewan Komisaris Yang Efektif, Jurnal Manajemen Usahawan Indonesia, XXXVI (11).

Reny, Denies Priantinah. (2012). Pengaruh Good Coporate Governance dan Pengungkapan Corporate Social Responsibility Terhadap Nilai Perusahaan (Studi Empiris pada Perusahaan Yang Terdaftar di Bursa Efek Indonesia Periode 2007-2010). Jurnal Nominal, 1(1).

Saputra, Mulia (2010). Pengaruh Corporate Governance Terhadap Nilai Perusahaan di Bursa Efek Indonesia, Jakarta, Journal of Indonesian Applied Economics, 4(1), 8192.

Siallagan, Hamonangan dan Machfoedz, Mas'ud. (2006). Mekanisme Corporate Governance, Kualitas Laba Dan Nilai 
Perusahaan. Simposium Nasional

Akuntansi IX. Padang.

Thomsen, Steen. (2006). The Hidden Meaning of Codes: Corporate and Investor Rent Seeking, European Business Organization Law Review, Issue 4, Cambridge University Press. 